Document downloaded from:

http://hdl.handle.net/10251/63509

This paper must be cited as:

Perales Monparler, S.; Andrés Doménech, I.; Andreu Alvarez, J.; Escuder Bueno, I. (2015). A regenerative urban stormwater management methodology: the journey of a Mediterranean city. Journal of Cleaner Production. 109:174-189. doi:10.1016/j.jclepro.2015.02.039.

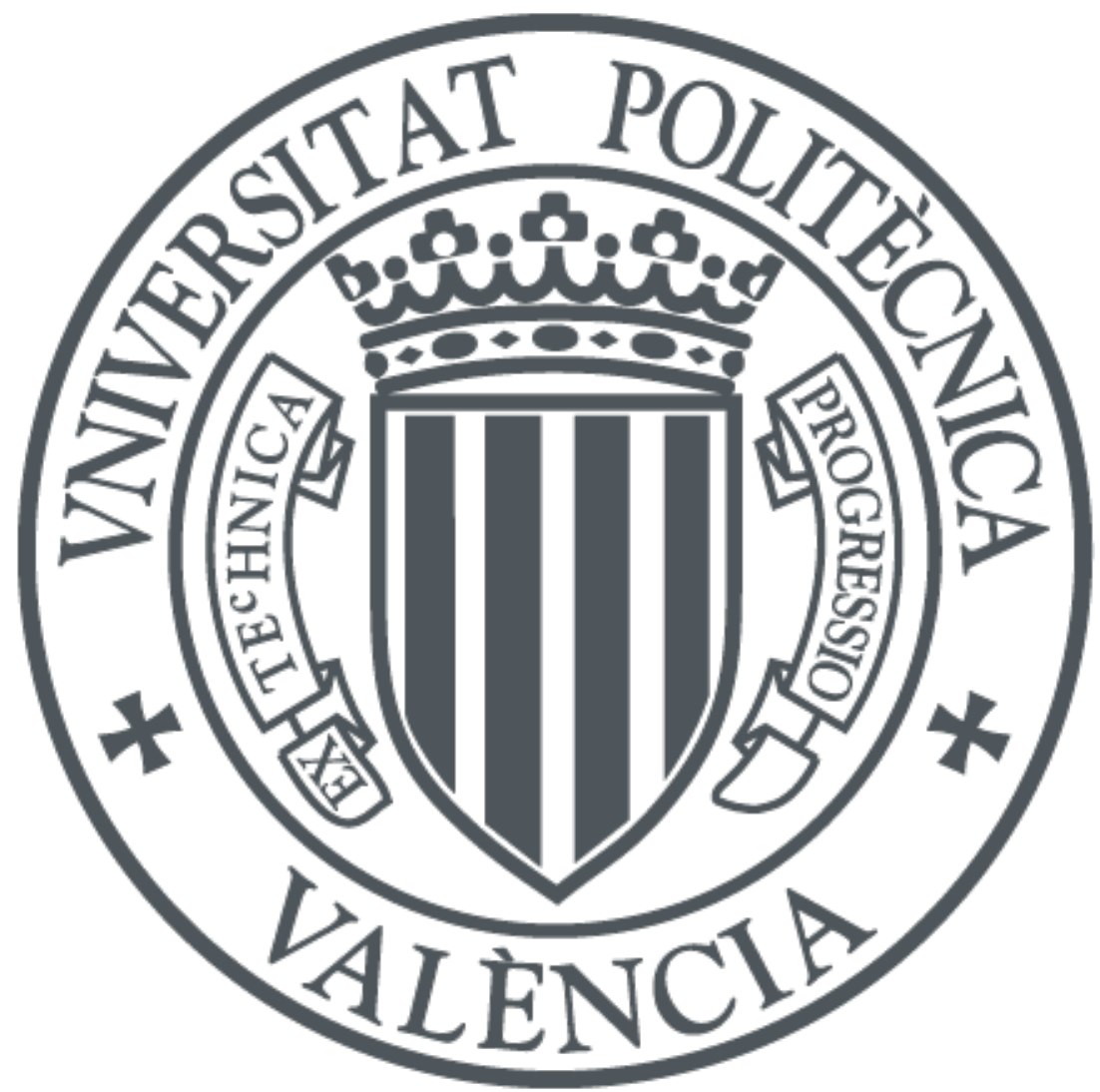

The final publication is available at

http://dx.doi.org/10.1016/j.jclepro.2015.02.039

Copyright Elsevier

Additional Information 


\title{
A regenerative urban stormwater management methodology: the journey of a Mediterranean city
}

\author{
Sara Perales-Momparler ${ }^{\mathrm{a}}$, Ignacio Andrés-Doménech ${ }^{\mathrm{b}}$, J oaquín Andreu ${ }^{\mathrm{b}}$, Ignacio \\ Escuder-Bueno ${ }^{b}$ \\ a PMEnginyeria. Avda. del Puerto, 180-1B. 46023 Valencia. Spain. \\ ${ }^{b}$ Universitat Politècnica de València. Instituto Universitario de Investigación de Ingeniería \\ del Agua y Medio Ambiente (IIAMA). Cno. de Vera s/n. 46022. Valencia. Spain.
}

\begin{abstract}
Urban drainage patterns are altered by increasing urbanization and rapid conveyance and discharge of runoff, leading to increased flood risk, diminish of aquifer recharge and degradation of receiving waterways. These effects are expected to escalate with climate change. In response, alternative and more sustainable drainage practices with a holistic approach have been developed, although their wide-scale implementation has been limited largely due to socioinstitutional barriers. This paper presents an innovative regenerative urban stormwater methodology for transition management at city level, containing two main enablers to overcome the barriers that drag out progress. First, a structured set of activities, the 'wheel', to guide and document the process, which is steered by a group of regional actors. Then, a visual and effective set of indicators that monitors and assesses the progress achieved and identifies the strategies to move forward. Its successful application to Benaguasil, a Mediterranean city, reveals that by integrating the views and strategies from actors at different but interconnected scales and following a structured but flexible methodology, it is possible to make progress in only few years and have a promising future ahead.
\end{abstract}

Keywords: Built environment, Mediterranean cities, Regenerative, SuDS, Transition management, Urban stormwater management.

Abbreviations: CSOs, Combined Sewer Overflows; DST, Decision Support Tool; ERDF, European Regional Development Fund; RWG, Regional Working Group; SuDS, Sustainable Drainage Systems; USWM, Urban StormWater Management. 


\section{I ntroduction}

Urban drainage patterns are altered by increasing urbanization and soil sealing, leading to increased flood risk and diminish of aquifer recharge (European Commission, 2012). Traditional practice in many countries considers urban stormwater as a waste product instead of a precious resource, and its rapid conveyance and discharge contributes to the degradation of receiving waterways: combined sewer overflows (CSOs), diffuse pollution, etc. (AndrésDoménech et al., 2010; Campbell et al., 2004). These effects are expected to escalate with climate change: extreme rainfall changes in the range $10-60 \%$ may lead to changes in flood and CSOs frequencies and volumes in the range $0-400 \%$ depending on the system characteristics (Willems et al., 2012); action cannot be further delayed and needs to be taken with an adaptive approach that involves, in addition to investments, active learning and consideration of the interrelationship of the economic and social challenges facing cities around the world (Arnbjerg-Nielsen et al., 2013; Gasper et al., 2011).

In response, alternative and more sustainable drainage practices with a holistic approach (also considering energy efficiency, social amenity, biodiversity, urban heat island effect, etc.) promoting sustainable urban drainage systems (SuDS) have been developed and implemented in many cities in the last 20-30 years (Marsalek and Chocat, 2002; Novotny et al., 2010), although only a limited acceptance can be found around the Mediterranean (Castro-Fresno et al., 2013; Charlesworth et al., 2013; Chouli et al., 2007; Perales-Momparler and VallsBenavides, 2013), where there is a need to create showcases to demonstrate the feasibility and suitability of new solutions in the long term (Casal-Campos et al., 2012).

Despite the multiple benefits of SuDS (Apostolaki et al., 2006; Charlesworth, 2010; Lundy and Wade, 2011; USEPA, 2008), their wide-scale implementation has been limited (Brown, 2005), with many cities investing heavily in the conventional approach (Wong and Brown, 2009). Insights from different studies on integrated urban water management reveal that barriers are largely socioinstitutional rather than technical (Brown and Farrely, 2009; Rauch et al., 2005) and recommendations call for collaborative planning and multi-stakeholders platforms that involve civil society (Potter et al., 2011; Sanchez-Rodriguez, 2009; van Herk et al., 2011) to deliver a shared vision for the cities of the future (Binney et al., 2010).

Hence, a radical change is required in culture as well as institutions (Pal-Wostl et al., 2008) in order to limit and potentially reverse damage to ecosystems (Pedersen-Zari, 2012). Consideration must be given to the interrelationship of urban stormwater management (USWM) with other sectors (e.g. energy, transport, urban planning, health) (du Plessis, 2012) through a systems thinking, building capacity, building natural and social capital approach, which are the aspirations of regenerative design and development (Cole, 2012b). 
Transition management emerges in the literature as a sound governance approach to bring about the required change of paradigm (Frantzeskaki et al., 2012; Tukker and Butter, 2007). However, there is a need for research that puts cities in focus rather than countries or buildings (Cole, 2012b; McCormick et al., 2013). Existing conceptual models need to be updated and improved to address the complex reality of urban areas (Ferguson et al., 2013a; Sanchez-Rodriguez, 2009), and the question of what tactical and operational transition management looks like needs to be addressed (Loorbach and Rotmans, 2010). With much of the literature focusing on barriers to change, successful case studies are required (Brown et al., 2009) with positive vision and narratives to encourage collective action to solve environmental problems (Smith and Raven, 2012), transitioning towards regenerative urban built environments.

The aim of this paper is therefore to develop a methodology, with a conceptual framework, specific method and tools, placing the focus on municipal infrastructure systems or sub-systems (USWM in this case). With a place-based holistic view, the proposed methodology allows for the understanding and the characterization of the current situation in a process that guides future actions to move towards the desired regenerative urban built environment concept.

This methodology has been applied to Benaguasil, a Mediterranean city where stormwater management is the local authority's responsibility but has been historically guided by mainstream conventional drainage practices. The paper shows how, by taking a multi-dimensional and trans-disciplinary approach to solve environmental problems, future actions can be properly addressed. Working with academia has been essential to develop wider evidence base (Hoxie et al., 2012). In this case, a sequence of research projects has advanced the innovative approach to stormwater management in Benaguasil, but it is contended that this methodology could be applied to any urban context.

\section{Proposed methodology}

Under the well-known slogan 'think global, act local', cities in the $21^{\text {st }}$ century face the enormous challenge of catalyzing, intensifying and accelerating sustainable urban transformations, that can be defined in two dimensions: first, drivers of 'radical' change, such as governance and planning, innovation and competitiveness, and lifestyle and consumption; and, second, 'multi-dimensional' sustainable urban structures, which include resource management and climate mitigation and adaptation, transport and accessibility, buildings, and the spatial environment and public space (McCormick et al., 2013).

Without losing this holistic view, the methodology presented herein places the focus on 'resource management and climate mitigation and adaptation', in particular in USWM, proposing processes that can bring about the required 
change, shaped by the place-based approach of the regenerative sustainability paradigm (Mang and Reed, 2012).

\subsection{SuDS as a regenerative development instrument}

A relatively new and flexible approach to urban stormwater management has emerged that makes a switch from piped engineered systems to practices and systems that use and enhance natural processes (infiltration, evapotranspiration, filtration, retention, reuse) to mimic the site predevelopment hydrology.

Known under different names across the globe, the term Sustainable Drainage Systems (SuDS) is used throughout this article to refer to this approach. SuDS currently in use include green roofs, rain gardens, permeable pavements, infiltration basins and daylighting of culverted water bodies; they can be combined with conventional techniques (pipes) and retrofitted into existing drainage systems. While conventional drainage focuses on stormwater quantity management (rapid collection and conveyance to receiving bodies, without previous treatment in many cases), SuDS place equal emphasis on water quantity, water quality, amenity and biodiversity, the three spheres of the SuDS 'triangle' (Woods-Ballard et al., 2007). In addition, there are other benefits that SuDS can provide (specially the vegetated devices) that are important to consider in a changing climate. Carbon sequestration and storage, urban cooling, flood resilience, human-health and well-being have been incorporated by Charlesworth (2010) into the representation of SuDS, baptizing the new one as the SuDS 'rocket'.

Best practice utilizes a chain of SuDS devices, a 'management train', to mimic natural catchment processes as closely as possible. This prioritizes prevention and control of water at source (i.e. green roofs, pervious pavements, bioretention areas) before considering site or regional controls (i.e. wetlands, ponds) (Woods-Ballard et al., 2007), although this is not always the approach followed in practice (Bastien et al., 2010). In mimicking nature, SuDS can provide 'ecosystem services' such as water resources, flood protection, biodiversity, climatic regulation, recreation, aesthetic inspiration, opportunities for social interaction, stress reduction, environmental education, healthier and more livable cities (Apostolaki et al., 2006; Jones and Davis, 2012; Hamel et al., 2013; Novotny et al., 2010), contributing to the positive integration with, and restoration of, local ecosystems (Pedersen-Zari, 2012), and can help cities transition towards more sustainable environments which are more resilient to changing future conditions (Lundy and Wade, 2011).

However, it is important to integrate strategic resource management with urban spatial planning (Agudelo-Vera et al., 2011), which for stormwater management includes adapting urban layout to existing water corridors and patterns (Perales et al., 2011). Moreover, promotion of character in townscape and landscape "rooted in the context and its social-ecological narratives" (du Plessis, 2012) 
must be embraced by the different agencies working in the region (Biddulph, 2011). Hence, a new representation for the regenerative approach to stormwater management is proposed: the SuDS 'landed rocket' (Figure 1). In doing so, we incorporate the connection to the place, in a way that people "are vitalized and become intrinsically motivated to care for it" as a result, bringing about "the transformation of our cities into places that are life enhancing and regenerative" (Mang, 2009).

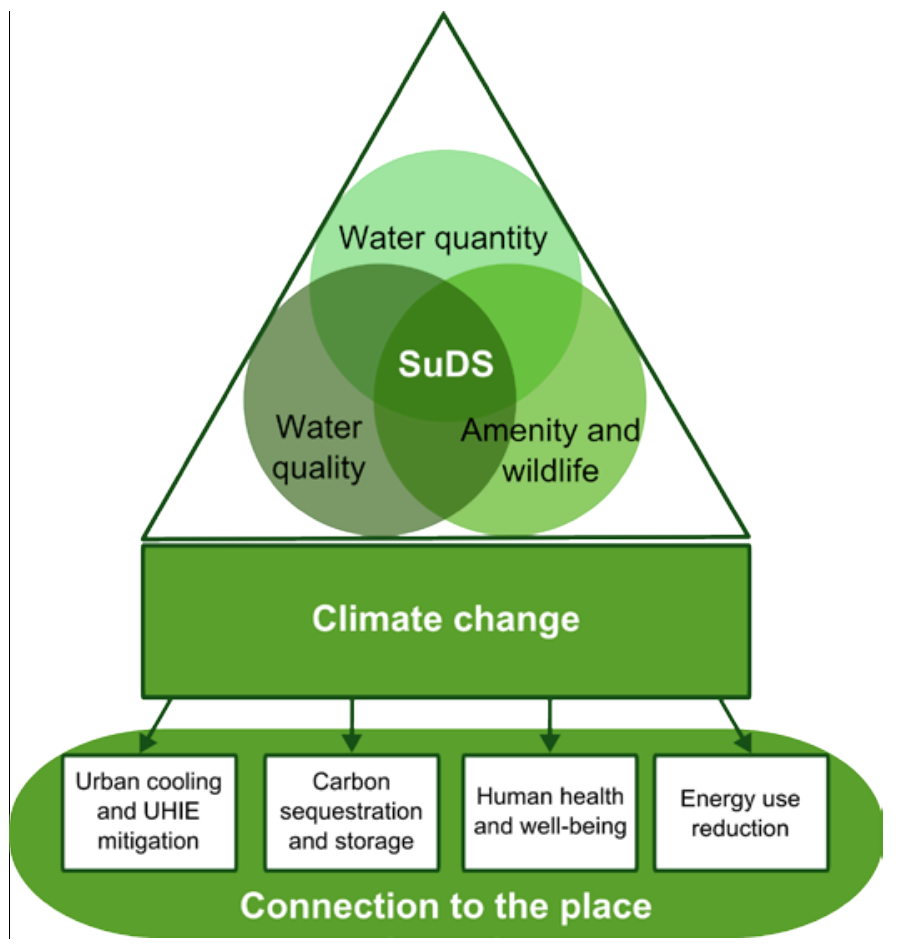

Figure 1. The SuDS landed rocket (after Woods-Ballard et al., 2007 and Charlesworth, 2010).

From the above, we understand that, if properly designed and integrated, SuDS could comply with the three insights that form the basis of the regenerative paradigm (du Plessis, 2012): a) necessity to follow a development approach based on how nature works; b) interpretation of the world as an ever-changing, impermanent and inherently unpredictable set of processes; and, c) the notion that humans participate in the production, transformation and evolution of the ecosystem in which they find themselves.

The desired transformation of cities, from the lens of USWM while understanding the breath of the whole system, is depicted conceptually in Figure 2. It builds on work by Reed (2007) and incorporates four representations of stormwater practices nested into the SuDS 'landed rocket' (Figure 1). They relate to the nested levels of progression towards a regenerative design: while green design is primarily directed at doing 'less harm', sustainability is a 'neutral' state that provides the necessary base condition to permit regenerative capabilities to evolve (Cole, 2012b). Regeneration is about engaging the "entirety of what makes a place healthy", entering an 'evolutionary spiral' in which three essential 
aspects catalyze the design process: "understanding the master pattern of place; translating the patterns into design guidelines and conceptual design; and, ongoing feedback - a conscious process of learning and participation through action, reflection and dialogue" (Reed, 2007).

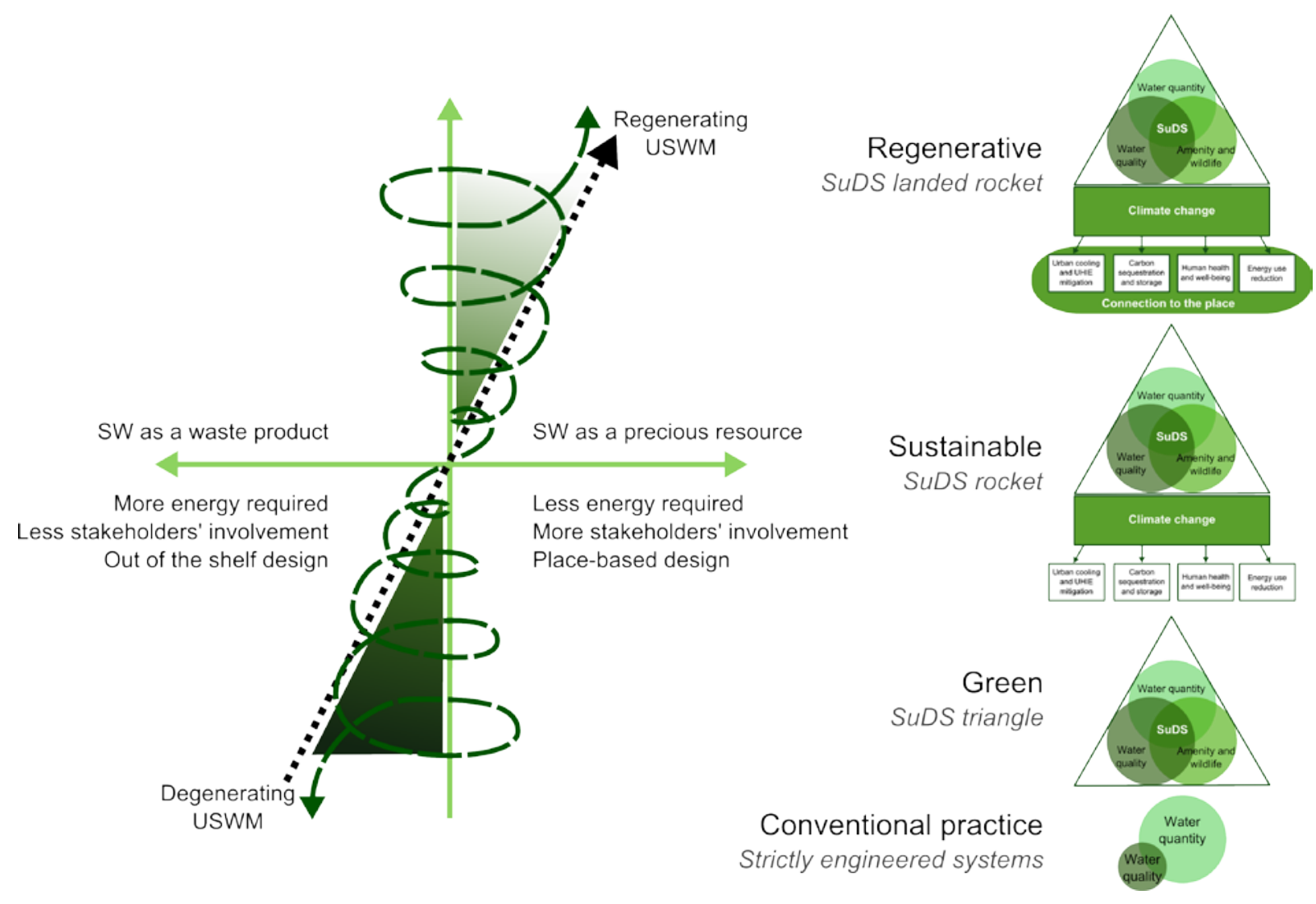

Figure 2. Trajectory of Environmentally Responsible Stormwater Management (after Reed, 2007).

The 'Leapfrogging' concept (J efferies and Duffy, 2011) applies to Figure 2. Cities currently in the lower part of the trajectory could find paths to avoid intermediate practices (i.e. going directly from conventional practices to regenerative ones for new and retrofitting schemes), and developing cities could avoid mistakes and limitations of the slow route.

\subsection{Steering the wheel: the 'Sustainable Transition Management Cycle'}

Sustainable transitions such as those which move towards a regenerative approach to stormwater management have additional complexities to many historical transitions, as they are goal-oriented, addressing persistent and new environmental collective problems, which with achievement do not offer obvious local, immediate, visible and tangible user benefits (Geels, 2011). In addition, scale and context-dependencies of cities present huge challenges to a transition toward sustainability/regeneration (Næss \& Vogel, 2012). This makes the participation of public authorities and civil society crucial to a sustainable transition (Elzen et al., 2011). 
Governance and planning, in particular the way for stakeholders to collaborate, have been identified as critical to transformative change towards urban sustainability (McCormick et al., 2013), and transition management emerges as an innovative approach for dealing with the complex, uncertain and multifacetted problems of water management (van de Brugge and Rotmans, 2007).

SWITCH (Sustainable Water Improves Tomorrow's Cities Health) was an EU funded action research program which overall goal was to catalyze change towards more sustainable urban water management in the 'City of the Future' (van der Steen and Howe, 2009). A final output of this project is 'The SWITCH Transition Manual', whose purpose is "to provide a coherent methodology to enable a city to change its water system from today's state into a better condition in the future" (J efferies and Duffy, 2011).

In the methodology presented in this paper, we make use of part of the SWITCH project transition framework to guide the cities' 'regenerating trajectory', which has been selected for its city-water approach that builds on transition theory. 'Steering the wheel' should not be viewed as a way to control societal changes; by contrast it is a method for the exploration in a reflexive manner of a new city governance approach (Nevens et al., 2013).

Building upon four different approaches to transitioning (the multi-phase concept, the multi-level perspective, transition management and strategic niche management), the 'SWITCH Transition Framework' (Duffy and Jefferies, 2011) is intended for decision makers at national and local scales, being of great assistance also to urban water practitioners and decision makers in the urban water sector.

At the core of the framework, lies the so called 'Sustainable Transition Management Cycle', which consists of ten activities that take place at three management levels (Figure 3): Strategic, where long-term ambitions and goals are formulated, requiring strategic thinkers that are open to change and reflection; Tactical, aiming to gain societal support and attention for sustainability objectives and intermediary goals, by developing networks and coalitions that can identify and overcome structural barriers; and, Operational, based on short-term experimenting with innovations that have potential to materialize the strategic vision, informing actors about specific barriers in different environments (Loorbach, 2007). These levels do not represent a hierarchy and although different types of actors participate at each level, a diverse set of competencies and skills are required across all levels (J efferies and Duffy, 2011). 


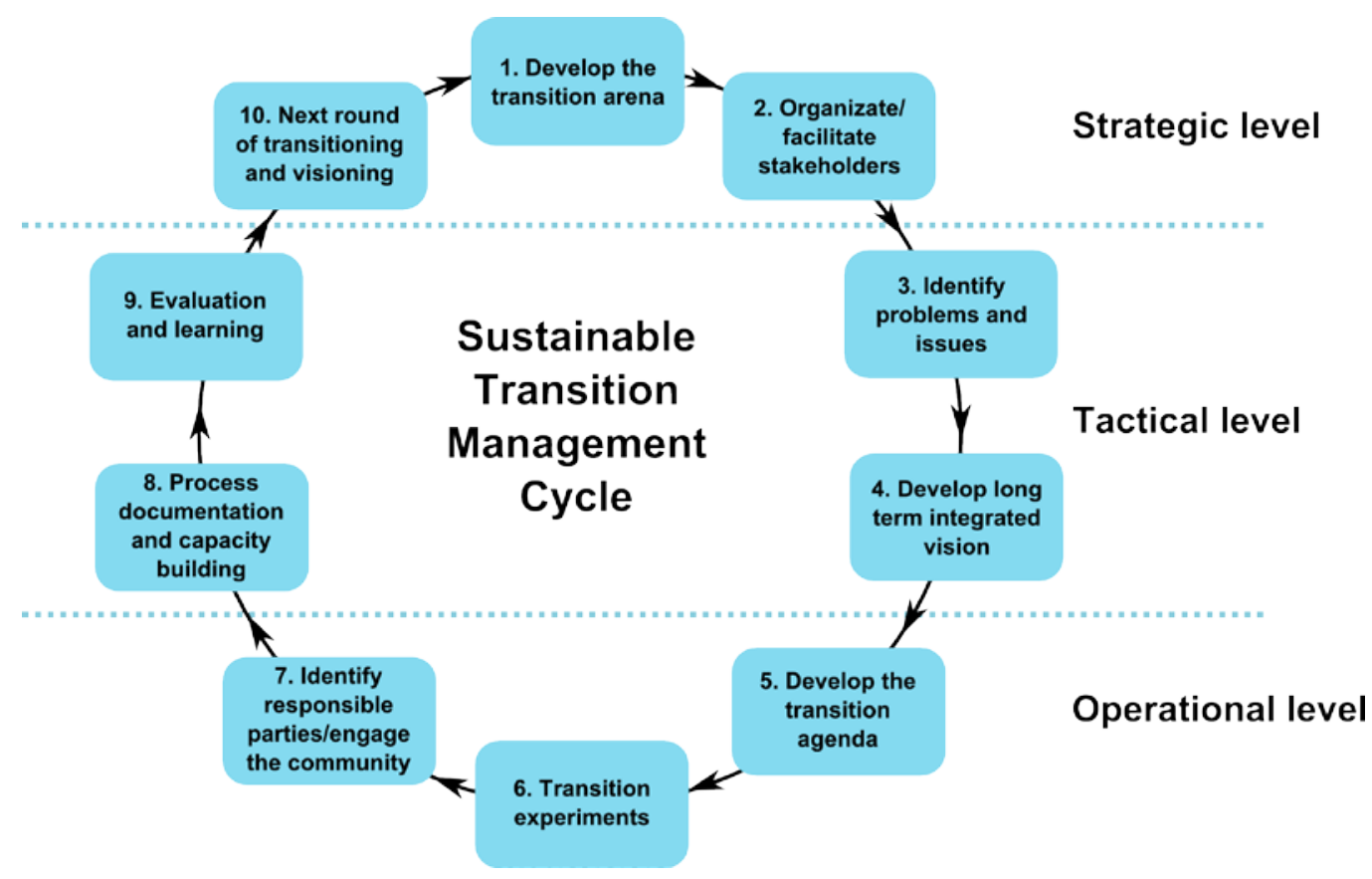

Figure 3. The Sustainable Transition Management Cycle (Adapted from Duffy and Jefferies, 2011).

The Sustainable Transition Management Cycle is driven by the SWITCH so called 'Learning Alliance', a stakeholders group made up from government bodies, user groups and research institutions that bring new ideas, techniques and innovations into a city, and has strong powers of influence in commissioning and nurturing projects that demonstrate the implications of the transition being promoted in the city. Throughout this paper, the Sustainable Transition Management Cycle will be referred to as the 'wheel', whereas the 'Learning Alliance' will be the Regional Working Group (RWG). A frontrunner capable of effectively engaging relevant stakeholders in the region is crucial for the creation and coordination of an RWG that endures with time.

We propose to use the 'wheel' to classify the activities carried out in the case study, so an assessment can be made of the strengths developed over time as a way to 'measure' the progress achieved along the transition pathway. The numbering of the activities does not imply any implementation order, as strengths can be developed in any sequence. However, numbers have been added in Figure 3 to facilitate the consequent analysis.

\subsection{Institutional work on innovation trajectories}

Barriers to advancing sustainable urban water management have been identified as largely socio-institutional rather than technical (Brown and Farrely, 2009), justifying placing the focus on institutions (Geels, 2004), the actors and their strategies when analyzing socio-technical transitions to sustainability (Díaz et al., 2013). Brown et al. (2013) highlight the importance of institutional work on transition management, suggesting that "more emphasis should be given to this interplay between frontrunners, visions and experiments on the one hand and 
institutional strategies and structures on the other". Hence, the formation of new networks such as the RWG, where each member can be a frontrunner in their institution, plays an important role in framing sustainable urban development (Woolthuis et al., 2013).

Although it is common to represent transitions at the system scale (Geels and Schot, 2007), we focus our transition analysis on one part of the system (Loorbach and Rotmans, 2010), i.e., USWM versus urban water management. Furthermore, conceptualizing the SuDS 'landed rocket' as an individual 'constellation' within the USWM system, it is possible to identify what type it is according to its 'degree of influencing' ('share of power') of the overall system (de Haan and Rotmans, 2011): regimes are the most powerful, niche-regimes have moderate power, niches have low power and pre-niches have no power. This classification has been used by Ferguson et al. (2014) to identify the stage of maturation of an individual constellation over time, using the multi-phase Scurve (Rotmans et al., 2001) and its four stages of a transition: predevelopment, take-off, acceleration and stabilization. Consequently, when identifying the maturation stage of the constellation of study and its alignment with the established regime, work by Ferguson et al. (2014) provides some light on the type of institutional work required to support the innovation maturation (Figure 4).

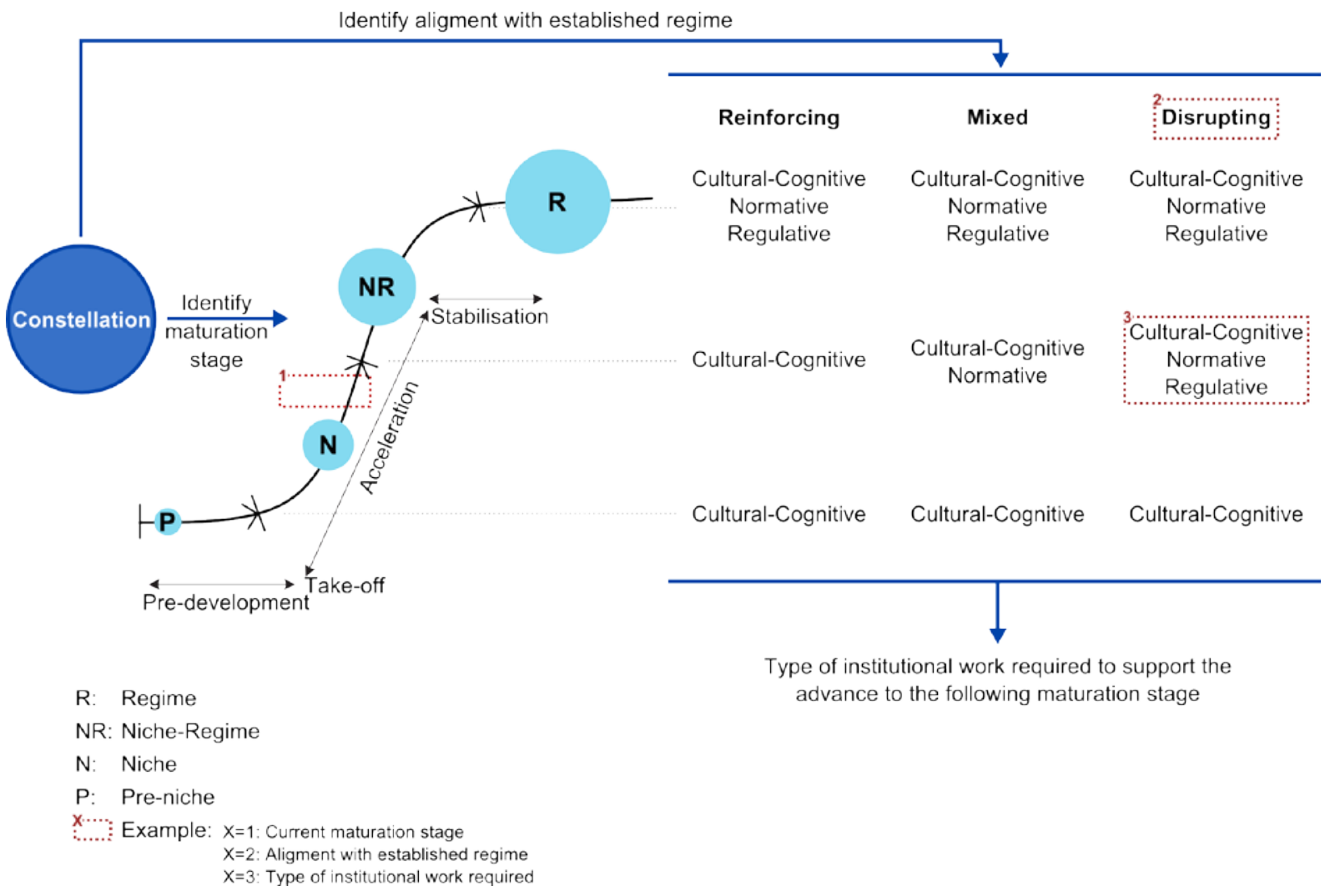

Figure 4. I dentification of the type of institutional work required for supporting key maturity stages (Adapted from Ferguson et al., 2014). 
To complete the analysis, we use the classification of 'institutional work' by Ferguson et al. (2014) to present enablers and barriers found in the case study, and compare them with the main type of barriers found by Brown and Farrely (2009).

\subsection{A regenerative urban stormwater management methodology}

The methodology we propose for approaching the concept of regenerative urban built environment focuses on municipal infrastructure systems or sub-systems (in this case USWM) with a holistic view. This is a step forward from the more common situation where it is applied to buildings or particular developments (Cole, 2012b). It is intended to be used at a local level, with a place-based approach that integrates and frames planetary issues (such as energy and global warming) "in manageable, meaningful and, literally, grounded context" (Reed, 2007).

\section{A Regenerative Urban Stormwater Management Methodology}

\section{Tier 1: Guiding Premises and Concepts}

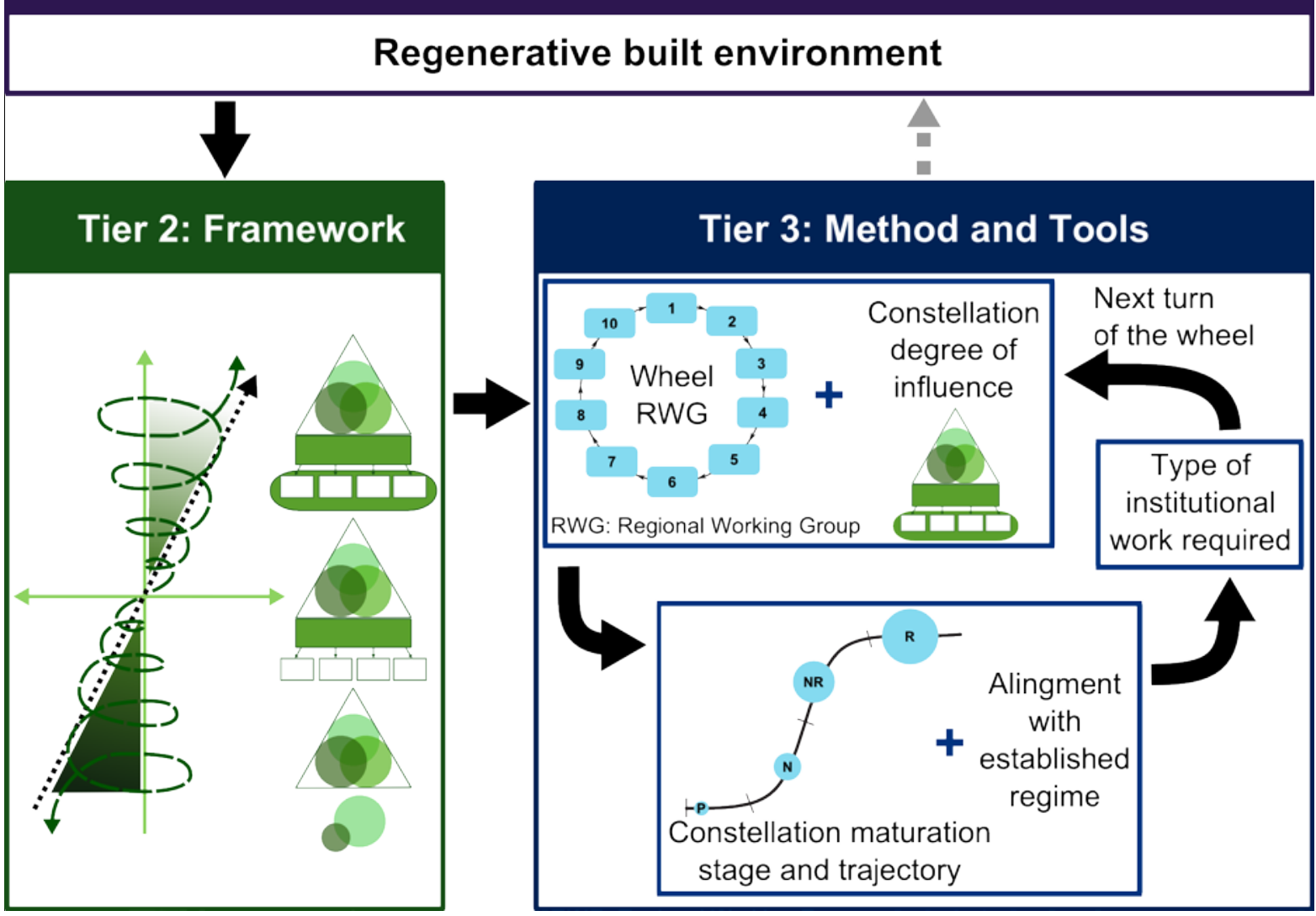

Figure 5. A regenerative urban stormwater management methodology. Solid arrows show the route between tiers and link the cyclical steps within Tier 3 . The dashed arrow represents the possibility to refine concepts during the process. 
This methodology (Figure 5 ) is based on that proposed by Mang and Reed (2012), adapted to deal with USWM, and includes the framework and the method and tools previously described in this section, with the aim of advancing the SuDS 'landed rocket' (the constellation) within the vision of a regenerative built environment. It is structured in 3 tiers: Tier 1 presents the thinking behind tiers 2 and 3, the desired paradigm: a regenerative built environment; Tier 2 depictures the theoretical framework (Figure 2), that enables comprehending and visioning of the complex systems analyzed, USWM in this case; and, Tier 3 provides practical method and tools for advancing in the desired direction, "engaging the people who will need to sustain and develop the process over time" (Mang and Reed, 2012).

A theoretical application of this framework would start in Tier 1 by defining which is the desired paradigm and continue with depicting the framework to journey towards it, Tier 2 . Then the proposed method and tools presented in Tier 3 would be followed in a cyclical way, starting from scratch. However, real cities might have travelled part of the journey without framing it within a conceptual model and formal definition of Tiers 1 and 2 could happen on the way. This is what happened in Benaguasil, the case study presented in sections 3 and 4 . In addition, progress within Tier 3 could suggest refinements of concept in Tiers 1 and 2 (e.g. adding a new parameter along the $x$ axis in Figure 2).

In Tier 3, the first step is to examine the strengths already developed within the wheel activities (Figure 3 ) and the relative degree of influence of the SuDS 'landed rocket' within the current USWM system. This analysis allows depicting the stage within the constellation maturation curve and the alignment with the established regime at present. Consequently, the type of institutional work required for supporting key maturity stages is identified (Figure 4), which can be linked to particular activities programmed to develop strengths within the wheel. After a period of time, the analysis will be conducted again, assessing the progress achieved and planning the following turn of the wheel.

Strengths developed within each turn of the wheel can be color coded. The size of the balls that represent the constellation stages are linked to their 'degree of influencing' of the overall system (i.e. the most powerful, regime, is represented with the biggest size ball). Hence, the wheel, together with the picture of the constellation maturation stage and trajectory, provide a visual and effective set of indicators to track progress and plan for future actions.

In the case study presented in sections 3 and 4, strengths developed are identified by naming actions undertaken within each activity, and expert judgment determines whether the strength has been developed lightly or strongly, as well as determining the SuDS 'landed rocket' maturation stages and trajectory. The alignment with the established regime is conducted by examining enablers and obstacles for each type of institutional work presented in Ferguson et al. (2014). Future research could lead to a parametric analysis being proposed 
for this examination. Furthermore, while we focus on the institutional work required depending on the constellation's alignment with the established regime, the methodology itself leaves the door open to embrace in the future additional tools and methods.

For simplicity, throughout the rest of this article we use the word SuDS to refer to the SuDS 'landed rocket' concept.

\section{Urban stormwater management in Benaguasil: the journey.}

The methodology presented has been applied to the journey of Benaguasil, a Mediterranean city, towards a regenerative built environment. With a mild and semi-arid climate, Benaguasil has an average annual rainfall of $432 \mathrm{~mm}$, with very strong seasonality. As many Mediterranean cities, it experiences very high peak rainfall intensities that concentrate in short periods of time, which together with city characteristics such as high population density (4 750 hab/ $\mathrm{km}^{2}$ in Benaguasil) and large impermeability, difficult urban stormwater management.

This section presents a longitudinal narrative of the case study research, establishing three key transitions states: historical, current and future (Brown et al., 2009; Duffy and Jefferies, 2011). The analysis of whether the actions undertaken have influenced the desired change and to what extent is presented in section 4.

The focus of the narrative and the consequent analysis is in the current state, which comprises activities that although not yet completed are well defined and planned. In-depth detail is given to the interplay between frontrunners and the institutions.

\subsection{The 'place' and its historical relationship with water (ancient times to 2008)}

Located $20 \mathrm{~km}$ inland from the city of Valencia (in the western Mediterranean on the Spanish coast) and currently counting with over 11000 inhabitants, Benaguasil has appreciated the value of water from ancient times, being essential for its agricultural based economy (Grau, 1995). Research by Nicolau (1990) brings to light documents from XIV to XIX centuries that reveal Benaguasil strong relationship with water: the main water supply source was the Turia river, from which water was gravity-transported using irrigation channels for drinking, housing and agricultural use, being as well the energy source for the flour mills. During rainy periods, when the river water turbidity was high, drinking water used to be manually extracted from few wells located in the 'villa', and cisterns were used to provide fresh water in summer periods.

Nowadays the town faces three major problems in terms of urban water management: frequent pluvial flooding and backup flows from overloaded 
combined sewers into dwellings, pollution of water courses from CSOs and high energy consumption. Believing that the solution could not come only from increasing the capacity of conveyance and treatment facilities, the Municipality of Benaguasil started to think 'out of the box', understanding that a more natural approach and raking up traditional practices might be needed.

\subsection{Transitioning towards a regenerative urban stormwater management (2008-2015 and beyond)}

Since 2008, Municipality of Benaguasil has been involved in several research projects at European level, looking for an alternative regenerative approach to traditional stormwater practice. Table 1 shows the chronology of the projects in which AQUAVAL and $E^{2}$ STORMED are the cornerstone projects, while the involvement in the SUFRI project and the PiP program built up on the efforts to achieve the desired transition.

\begin{tabular}{|c|c|c|c|c|c|c|}
\hline ACRONYM & FULL TITLE & PERIOD & $\begin{array}{l}\text { FUNDING } \\
\text { PROGRAMME }\end{array}$ & $\begin{array}{l}\text { BENAGUASIL } \\
\text { INVOLVEMENT }\end{array}$ & MAIN CONTRIBUTION TO THE JOURNEY & WEBSITE \\
\hline SUFRI & $\begin{array}{l}\text { Sustainable Strategies of Urban Flood } \\
\text { Risk management with non-structural } \\
\text { measures to } \\
\text { cope with the residual risk }\end{array}$ & 2009-2011 & $\begin{array}{l}\text { 2nd ERA-Net CRUE } \\
\text { Funding Initiative }\end{array}$ & Case study city & $\begin{array}{l}\text { Building relationships with university and } \\
\text { awareness of the need of a multidisciplinary } \\
\text { team to tackled a problem (pluvial flooding) }\end{array}$ & www.sufri.tugraz.at \\
\hline AQUAVAL & $\begin{array}{l}\text { Sustainable Urban Stormwater } \\
\text { Management Plans, promoting SUDS } \\
\text { and considering Climate Change, in } \\
\text { the Province of Valencia }\end{array}$ & 2010-2013 & $\begin{array}{l}\text { EU LIFE }+2008 \\
\text { Community Initiative } \\
\text { (European Regional } \\
\text { Development Fund) }\end{array}$ & Partner (1 of 5) & $\begin{array}{l}\text { Putting pilots in the ground and monitoring } \\
\text { their performance }\end{array}$ & www.aquavalproject.eu \\
\hline PIP & Pioneers into Practice & $2012-2014^{3}$ & $\begin{array}{l}\text { European Institute of } \\
\text { Innovation and } \\
\text { Technology (EIT) }\end{array}$ & Host institution & $\begin{array}{l}\text { Capacity building with pioneers with diverse } \\
\text { background from the region and other } \\
\text { European countries }\end{array}$ & $\begin{array}{l}\text { www.climate- } \\
\text { kic.org/pioneers }\end{array}$ \\
\hline$E^{2}$ STORMED & $\begin{array}{l}\text { Improvement of energy efficiency in } \\
\text { the water cycle by the use of } \\
\text { innovative storm water management } \\
\text { in smart Mediterranean cities }\end{array}$ & 2013-2015 & $\begin{array}{l}\text { EU MED Program } \\
\text { (European Regional } \\
\text { Development Fund) }\end{array}$ & Partner ( 1 of 9$)$ & $\begin{array}{l}\text { Applying the transition framework and } \\
\text { capacity building with regional institutions }\end{array}$ & www.e2stormed.eu \\
\hline
\end{tabular}

Table 1. Stormwater related European projects in which Benaguasil has been involved.

The narrative focuses on detailing the actor dynamics and the institutional work that is taking place in this phase, whereas the more technical aspects of the experiments are briefly mentioned. The main activities related to Benaguasil are shown in Table 2, which follows the activity classification of the Sustainable Transition Management Cycle. 


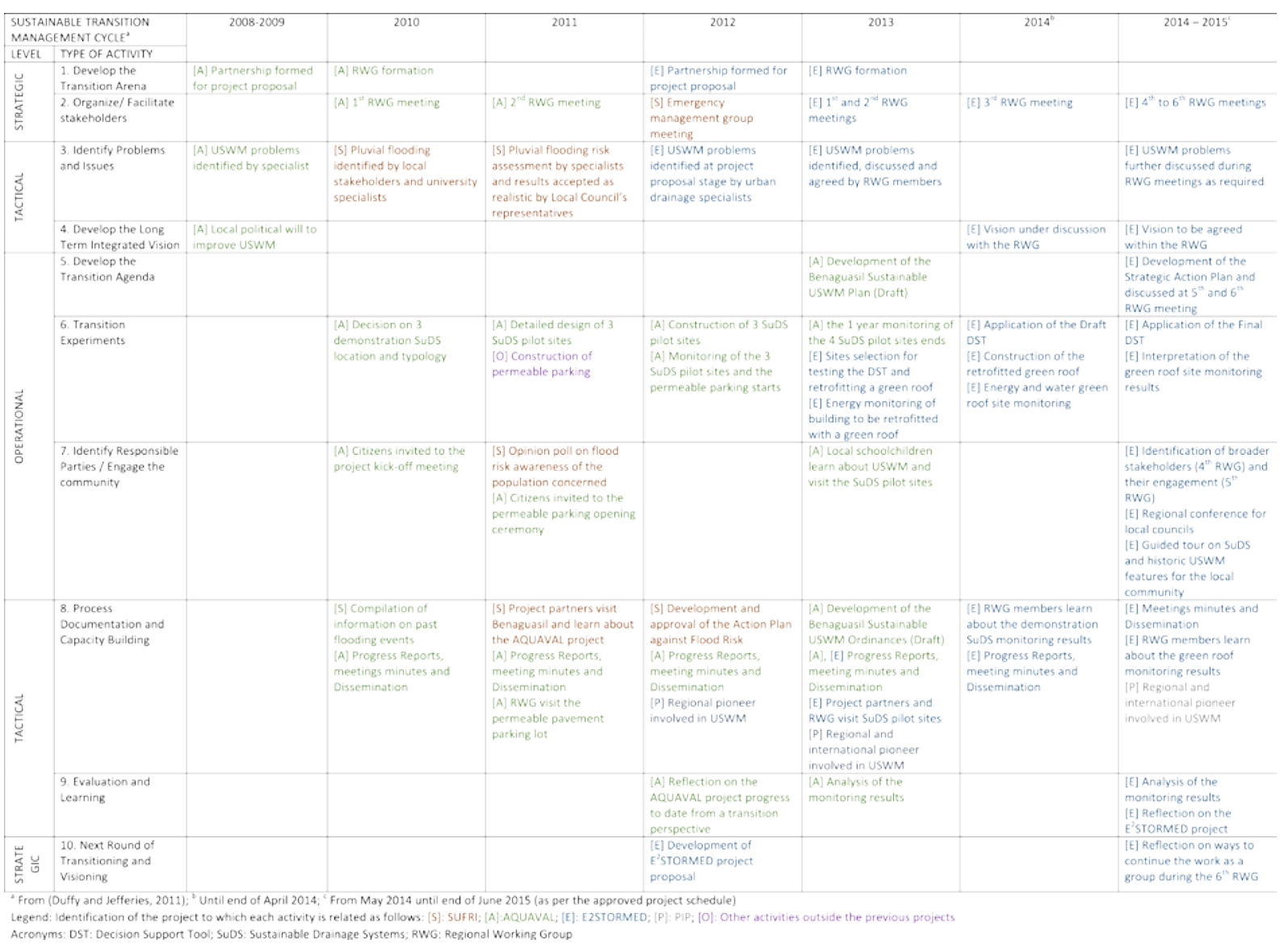

Table 2. Main activities undertaken during the stormwater related research European projects in which Benaguasil has been involved.

\subsubsection{Building the bridge}

The importance of individual frontrunners seen in the literature (Smith, 2007; Brown et al., 2013) is confirmed in this case study. In 2008, the first author of this article envisaged the opportunity to form a consortium in the Valencian Region of Spain to apply for European funding, in order to promote this innovative approach which was little understood in the country at that moment (Castro-Fresno et al., 2013; Perales and Andrés, 2008).

The partnership comprised two municipalities in the region (Xàtiva and Benaguasil), the frontrunner's consultancy firm, a UK University as an international expert on SuDS and a regional public entity that deals with EU relationships in the role of 'communication partner'. It counted with Diputació de València (county council) as co-financer for the construction of the proposed pilot SuDS sites. The project was approved for European Regional Development Fund (ERDF) co-financing and started in January 2010.

The inclusion of the Municipality of Benaguasil in AQUAVAL started its relationship with the 'ignition' frontrunner, who is linked to Universitat Politècnica de València (UPV). This link to the university located in the same region promoted the town to be one of the case studies for the pilot application of the 
SUFRI methodologies (Escuder-Bueno et al., 2012), highlighting the difficulty for local authorities to develop Municipal Action Plans against Flood Risk. UPV offered and agreed with Benaguasil Council's representatives, to develop such a Plan for the town as an additional task to the project. Following numerous meetings and conversations with local and regional stakeholders (local police, works' brigade, etc.) the Municipal Action Plan against Flood Risk for Benaguasil was approved by the Local Council in 2012, being the first Plan to be approved in the Region of Valencia under the current legislation.

\subsubsection{Crossing the bridge}

The guiding principle of AQUAVAL was to "make the best use of municipalities" landscape and morphology in order to integrate water infrastructure using SuDS, adding social and environmental values" (Perales-Momparler et al., 2013).

Three inner-city areas were selected and retrofitted to accommodate run-off from nearby surfaces, decreasing the flow rate and volume of stormwater that enters the combined sewer networks (frequently causing CSOs) or freely flows through the streets (occasionally flooding dwellings). The selection process (Casal-Campos et al., 2012) took 7 months, during which the responsible municipal councilor, the local technical architect and the regional SuDS expert meet 5 times, 2 of them also involving the international partner. Local stakeholders gained knowledge on this innovative stormwater management approach during the process, which led them to propose changing the projected impermeable car park of the new municipal swimming pool for a permeable one within the same budget. This car park was the first pilot constructed in Benaguasil using the new approach (increasing the number of pilots to four).

The four SuDS schemes were equipped with suitable instrumentation, and monitored for a year both in terms of runoff quantity and quality (Millán et al., 2013; Perales-Momparler et al., 2014).

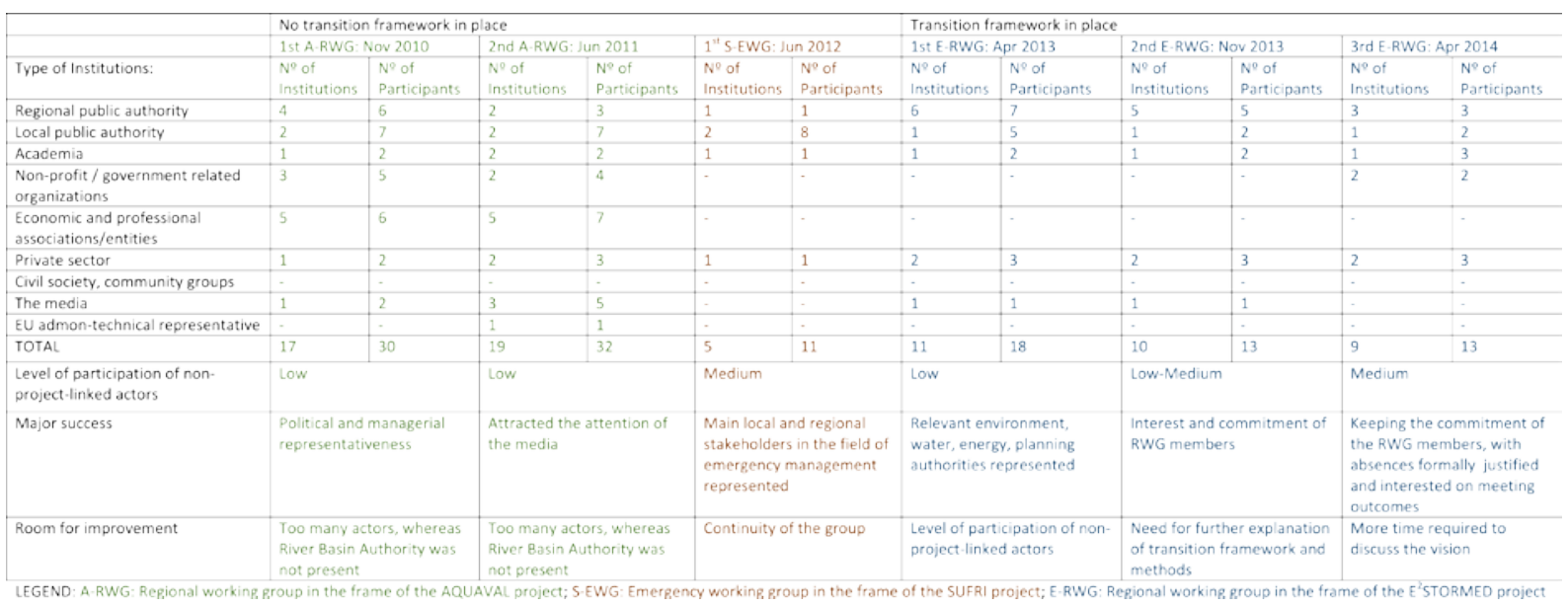

Table 3. Participation of stakeholders in meetings. 
Being the SuDS demonstration sites the core of the AQUAVAL project, additional groups of activities were undertaken (Table 2), including the creation and coordination of an RWG involving in the project actors from across the region in the water sector, public and private (with a high representation of design professions, e.g. architects and engineers, and the economic sector). The status of the 'communication partner', a regional public entity that deals with EU relationships, was essential in the successful response of the actors to the call to form the RWG, not only for the number of attendees (Table 3), but for the political and managerial representativeness, which attracted the attention of the media, with the opening ceremony of the public indoor swimming pool permeable car park ( $2^{\text {nd }}$ RWG meeting) being broadcasted by the regional TV at premium midday news program.

Despite the interest roused, this RWG only met twice at the first part of the project due to the fact that the 'communication partner' had to abandon the project in December 2011 and was not replaced.

\subsubsection{On the road}

In April 2012, the authors and the Municipality of Benaguasil envisaged that boosting this regenerative sustainability approach within the town and up-scaling and influencing standard practices would "require a programmatic rather than a single project-based approach" (McCormick et al., 2013). With this idea, and the will to extend this approach to other Mediterranean regions and link water management to other sectors such as energy, the E'2 STORMED project was born, approved for co-financing from the ERDF, and started in January 2013. It addresses the challenge of improving energy efficiency in the urban water cycle in Mediterranean cities by the use of innovative stormwater management systems. With 6 operational partners (local authorities) in charge of the implementation in their cities of the management tools developed by the two academic partners, it became feasible to verify the applicability of the theoretical practical tool and to demonstrate its real value for the municipalities (EscuderBueno et al., 2013).

In the case of Benaguasil, the most significant effort was at the beginning of the project in selecting the actors to form part of the E'STORMED RWG. The objective was to form a reasonable size group that allowed for a productive dialog, formed by key local and regional entities in urban planning, water and energy sectors, represented by a mixture of political, technical and managerial background actors. They would form the basis, the 'core' group, bringing in other stakeholders at different stages of the journey as considered appropriate. Due to the lack of strong community associations, citizens are not formally represented in the RWG at this moment, although their interests and needs are constantly taken into account (due to the relatively small size of the town, politicians are close to the citizens). 
This time the General Directorate of European Projects and Funds in the Valencian Region convened the selected actors and successfully hosted the first meeting, after which two additional ones have followed until May 2014 with a considerably constant number of attendees (Table 3 ).

To date (May 2014), in addition to cultural-cognitive institutional work on SuDS (putting in value results for the AQUAVAL monitoring campaign) and transition management, activities have focused on the identification of the problems faced by Benaguasil (frequent pluvial flooding, CSOs and high energy consumption) and the objectives that the strategy shall pursue (as an initial step of the visioning exercise). These objectives are (as per agreed on $2^{\text {nd }} \mathrm{RWG}$ ): reducing CSOs; protection of receiving water bodies; reducing energy consumption in the urban water management; landscaping integration of infrastructures; aquifer recharge; optimization of drinking water use.

$E^{2} S T O R M E D$ experiment activities consist of the selection of two areas within the city (an urban area that could be retrofitted and a future urban expansion) and the application of the Decision Support Tool (DST) developed by universities (Escuder-Bueno et al., 2013) to compare two different drainage scenarios in each area (one with conventional drainage infrastructure and one with the SuDS regenerative approach). In addition, a green roof has been retrofitted in a public building in Benaguasil, and its effects in energetic and hydraulic terms are being monitored.

The fourth European program involving Benaguasil is 'Pioneers into Practice' (PiP) (Table 1 ), hosting regional and international professionals/PhD students committed to tackle the climate change challenge. Pioneers are assigned sustainability-related work tasks during their 4-week placements (i.e. involvement in Benaguasil green roof design and monitoring), which turns on more professionals being aware of, and gaining experience on, regenerative stormwater management practices in the region and abroad.

It is worth mentioning that Benaguasil project activities are being echoed by RWG members using their own channels. Achievements at regional and international level with the AQUAVAL project are effective empowerment tool and fuel frontrunners expectations: selected as an example of good practice at European level (Progress Consulting S.r.I. and Living Prospects Ltd., 2011); nominated as finalist for the Novatech Awards, in the "City or catchment scale strategies" category (www.novatech.graie.org); and most important, included as example of the new indication to promote the use of SuDS in all urban areas of the Valencian Region added in the revision (under approval process) of the regional plan for flooding prevention (Resolution of $31^{\text {st }}$ October 2013).

Elicit a consensus vision for Benaguasil desirable future will be the main goal of the remaining RWG meetings, which is expected to be inspired on the regenerative USWM framework (Figure 2) and visioning exercises from the 
literature (de Haan et al., 2014). This vision will be shaped by interactive backasting (Næss \& Vogel, 2012; Quist et al., 2011) coupled with the development of Benaguasil Strategic Action Plan (Ferguson et al., 2013b; Truffer et al., 2010) for enabling the transition towards a regenerative stormwater management, taking as a starting point the draft Benaguasil Sustainable USWM Plan developed during AQUAVAL.

\subsubsection{Looking ahead}

It is the interest of the Municipality of Benaguasil to keep steering the wheel, learning from the past and preparing the next round of transition. Coalitions and collaboration between the RWG current members could make it possible, while aiming for a closer involvement of the regional productive fabric, with new work niches (i.e. specialists in green roof and other vegetated SuDS construction and maintenance) but also with the adaptation of more traditional sectors (i.e. ceramic and concrete) in the search for new products applicable to the regenerative approach.

\section{Analyzing the journey to date and envisioning the future}

The application of the proposed methodology to Benaguasil is an example of how it can be used even when the journey started prior to explicitly formalizing the desired paradigm and the visioning for USWM (Tiers 1 and 2). We identified that one cycle of Tier 3 had occurred before Tiers 1 and 2 where defined. Afterwards, in Tier 3 a second turn takes place, with more envisaged to follow.

The methodology, as applied in this case study: a) reconnects human aspirations and activities with the evolution of natural systems; b) brings a new way of thinking about how stormwater is managed in the built urban environment, c) gives the role of 'gardeners in and of place' to practitioners decision makers; and, d) works developmentally (taking systems to the next level), which according to Mang and Reed (2012), are the premises of a regenerative methodology.

SuDS mimic natural hydrology in urban environments while providing healthier and more livable cities. This methodology links stormwater management with other systems such as energy, and acknowledges that the SuDS approach needs to be integrated with a wide range of other strategies (Charlesworth, 2010). It highlights the relevancy of stakeholder involvement (Brown et al., 2013) and reconnects to the essence of place (which in the case of Benaguasil includes 'raking up' traditional practices like rainwater harvesting), enabling its regeneration and evolution (du Plessis, 2012) in a stepped and cyclical manner.

Data collection was conducted by the authors, directly involved in the process from the beginning. Afterwards, the longitudinal narrative presented in Section 3 was shared and agreed by Benaguasil council representatives. The analysis 
conducted herein by the authors follows opinions gathered from group interviews with 20 main actors of the RWG and 8 responses to a structured questionnaire.

\subsection{Advancing innovations by steering the wheel}

According to Nevens et al. (2013), "applying transition management in a city policy environment is a transition in itself", and that it is the main differential factor of the two turns of the wheel that we identify in Benaguasil transition to date (Figure 6).
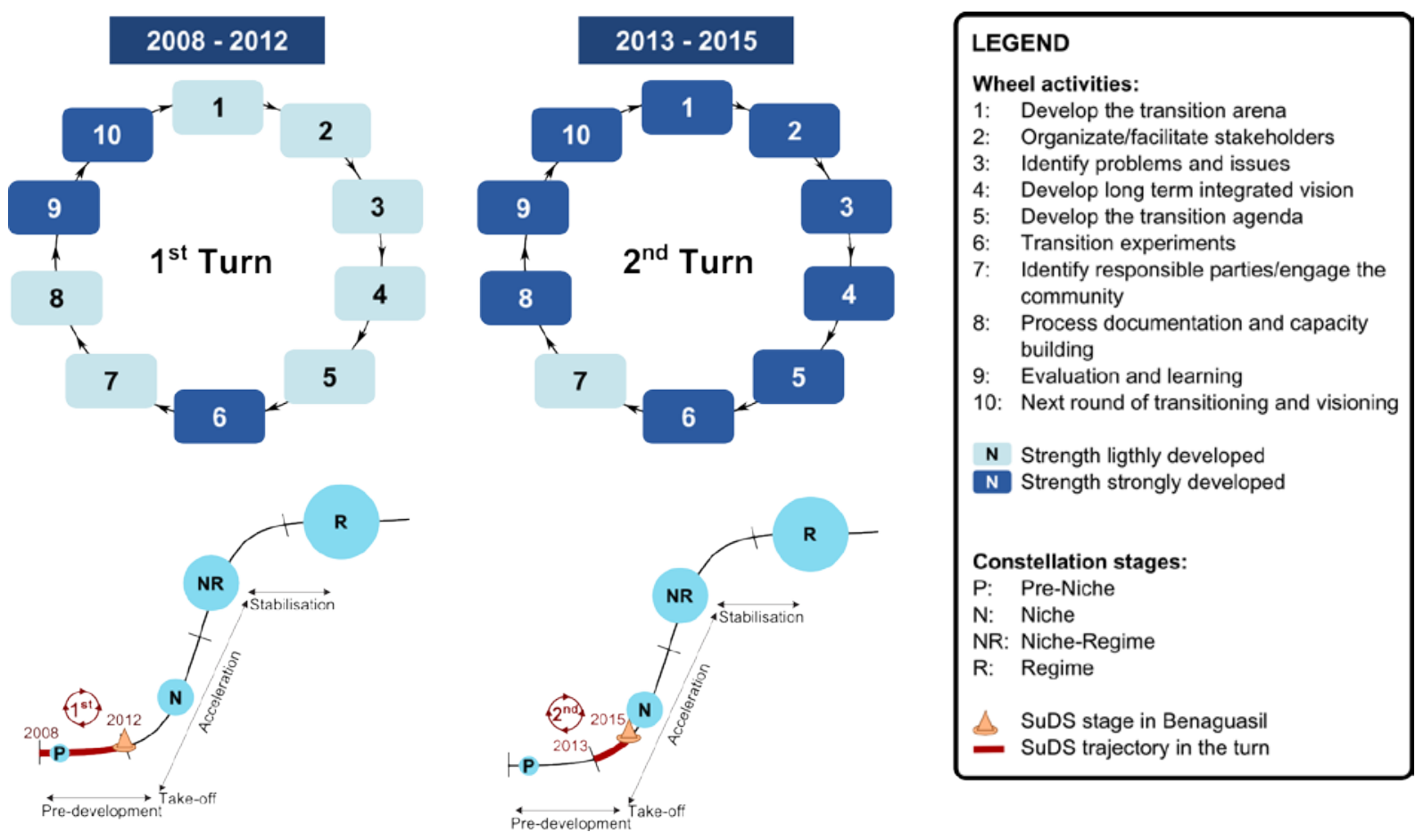

Figure 6: Set of indicators: identification of the strengths developed (upper part) and SuDS maturation stage and trajectory (lower part) of Benaguasil journey towards a regenerative USWM.

By analyzing the activities presented in Table 2, we conclude that by the end of the $E^{2}$ STORMED project (J une 2015) Benaguasil will have completed 2 turns of the wheel towards the desired regenerative USWM, having developed strengths in all activity types in different intensity during the process. Whereas in the first turn we consider that SuDS (an innovative approach with no influence in USWM practices at the beginning of the process) attained the niche stage in Benaguasil, progression on the acceleration section of the maturation curve is slow despite the application of transition management. This was predictable by looking at the steepness with which transition scholars have pictured this transition phase over the years.

As illustrated in Figure 6, the methodology that we propose provides a visual and effective set of indicators of strengths developed and SuDS maturation stages and trajectory progress achieved in Benaguasil in each cycle, highly important for 
understanding a multi-level and multi-dimensional process of change in which to base transition management interventions upon (Brown et al., 2013).

\subsection{Role played by actors and institutions}

The main result of the analysis of this case study, in line with other experiences in the literature (Brown et al., 2013; Loorbach and Rotmans, 2010), is the relevant role of the actors involved in the process. While the partners of the AQUAVAL project, through hard work and constant local political support in Benaguasil, were able to achieve the niche stage for the SuDS innovative approach, progression beyond that point was only marginally achieved (e.g. indication to promote the use of SuDS in all urban areas of the Valencian Region in regional legislation), although relevant.

Back-analyzing that first turn of the wheel, we think that the project partnership had a good balance of regional actors (two local authorities, one local SuDS expert firm, one strong communication partner and an overseas expert with an academic background), which strength was reinforced with the involvement of the 'close by' university (UPV) in monitoring and analyzing the SuDS pilot sites. However, the composition of the RWG was not thoroughly discussed, ending up being a too large group (with a high representation of design professions and the economic sector) who did not have a clear role in the process, whereas other potentially relevant actors were not present (e.g. River Basin Authority).

Reflection on the above led to the identification of the need for a methodology that could guide the process towards the desired regenerative urban built environment, in particular, in terms of selecting the actors with whom to continue the journey. Insights from the SWITCH project and partner cities experiences (J efferies and Duffy, 2011) were crucial to deciding which RWG members should steer the wheel. However, deciding the composition of a stakeholders group is not straightforward (Reed et al., 2009). The main difference in this second turn is that actors involved are aware that they are actually steering the wheel, and a methodology is in place to guide them, without relinquishing their power and duty of decision-making.

The fact that there are five additional Mediterranean cities in the $E^{2}$ STORMED project that are also steering their wheels, gives Benaguasil a platform to shear experiences with and learn from (with the valuable support of the two universities), while the well thought composition of the RWG (local and regional entities in urban planning, water and energy sectors, represented by a mixture of political, technical and managerial background actors), provides a clear role for each frontrunner. This 'core' group will be the one deciding what additional stakeholders need to be brought into at different stages of the journey, as considered appropriate. In the near future, it is scheduled that the identification of which broader stakeholders to involve in this second turn of the wheel takes place during the $4^{\text {th }}$ RWG, engaging them for the $5^{\text {th }}$ RWG (although it is 
expected to hold part of the meeting with only the 'core' actors present). By engaging the remaining stakeholders (social scientists, ecologists, economists, design professions, public health experts, business institutions, civil society, community groups, the media) as required in this last part of the $E^{2} S T O R M E D$ project, the 'core' RWG members can disseminate the project results as a common achievement, at the same time that with a shared vision, start to define what could be the role of the other actors in the next turn of the wheel.

While there have been activities for the local community and they are plan to continue (e.g. guided tour around SuDS pilot sites and historical water features, such as water mills and irrigation channels), we envisage that citizens will have a more relevant role to play in the future third turn of the wheel. Their stronger involvement would also provide robustness to the journey, as at the moment, and despite the active involvement of technical municipal staff, the process is highly political steered, and electoral changes or political decision at local and regional level could change the course of the transition (e.g. as was the case when the 'communication partner' abandoned the AQUAVAL project and that RWG did not meet again).

\subsection{Requirement for further institutional work}

Table 4 summarizes barriers and enablers that characterize the transition towards a regenerative USWM in Benaguasil. From the information in this table, the SuDS approach can be identified as 'disrupting' the established regime at the three institution types: cultural-cognitive, normative and regulative (i.e., need for new technical knowledge about SuDS, need to integrate ecologists, urban planners, landscape architects, etc. in communities of practices and need for private landowners to engage in providing source stormwater management). 


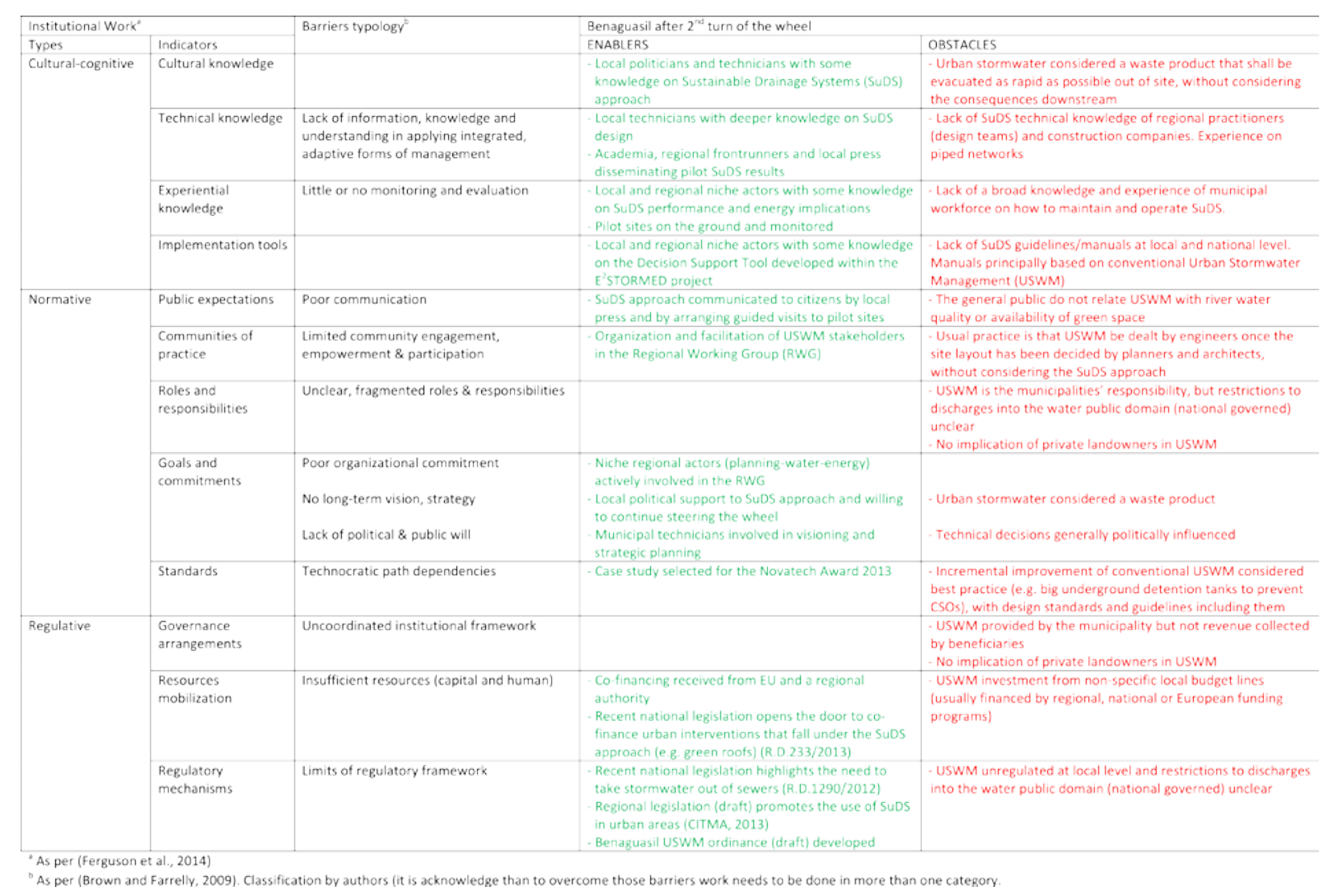

Table 4: Barriers and enablers in Benaguasil transition towards a regenerative USWM

Hence, supporting the SuDS approach maturation from niche to niche-regime will require further actions in all institutional work types (cultural-cognitive, normative and regulative) according to the hypotheses of Ferguson et al. (2014), which are aligned with the Benaguasil experience to date:

- First turn of the wheel: relating the potential benefits of SuDS (water quantity, water quality, amenity, biodiversity, link to the place) with impacts of landscape pressure (flooding, contamination of water courses, impacts of climate change) has allowed progression form pre-niche to niche, carrying mainly cultural-cognitive institutional work (e.g. dissemination of scientific knowledge; technology testing with practical experience on design and maintenance; gathering of empirical data from experiments that confirms SuDS benefits at the same time that provides learning experience for future applications). In addition, some preliminary ( not completed) work was undertaken in the normative (e.g. informal networks; draft Benaguasil Sustainable USWM Plan) and regulative (e.g. draft local ordinances for USWM) types of institutional work.

- Second turn of the wheel: progress has been achieved by reinforcing the cultural-cognitive type of work (e.g. developing and testing the tool for decision makers; dissemination of pilot SuDS monitoring results to a broader audience, including a regional conference for local councils) while focusing on normative work (e.g. bringing together key regional actors 
that, with a holistic view, shear visions and concerns, and work together to build a strategic program, with coordinated and co-supported actions, towards the achievement of common goals), something that we consider essential for the regulative mechanisms (e.g. municipal USWM ordinance) to be successful.

- Third turn of the wheel: we agree that further institutional work of all three types is required to mature the SuDS innovation towards a regenerative urban built environment. In particular, dissemination of results from the newly-installed green roof (cultural-cognitive), the commitment of regional institutions to implement the activities included in the Benaguasil Sustainable USWM Plan and the regular use of the DST (normative), and the approval of the municipal USWM ordinance (regulative), are envisaged to be key steps in the next turn of the wheel.

The journey of Benaguasil also confirms that the acceleration section of the road is much steeper that the pre-development one, as the more a disrupting innovation approaches the regime, the more barriers need to be addressed. Progress is slower, but possible with the support of a methodology as presented in this article.

\subsection{Envisioning the future}

We believe that in Benaguasil the seed is there to enable, shape and speed up the desired transition towards a regenerative USWM that evens the path for other Mediterranean cities to follow. As concluded by Brown et al. (2013), to influence the regime, the bridging function of the RWG, needs to "first focus on generating understanding, collating evidence and nurturing relationships, then build confidence amongst practitioners, up-skill and train a broad range of actors within the sector, then focus pressure towards generating policy shifts". The Benaguasil case study can contribute, together with other experiences rolled out in a city context (Nevens et al., 2013), to 'prove' whether transition management 'works', bringing the particularity that transition had started before the frontrunners were conscious of 'steering the wheel'. Despite all of the above, a successful transition is not guaranteed (Geels and Schot, 2007; Smith, 2007).

The transition in Benaguasil would benefit from testing emerging regenerative design frameworks (e.g. Plaut et al., 2012) in one of the planned new developments. It would be ideal for putting into practice concepts such as the place-based approach, which in terms of stormwater management could include reinforcing the role of the existing water mills and irrigation channels, and recovering the rainwater harvesting tradition. Including educational signs that guide the visitor along the tangible regenerative elements but also that tell the story of how a trans-disciplinary team were involved in the design process, during which "the role of the architect/planner/designer [shifted] to that of facilitator of a process of revealing, rather than acting as master mind" (du 
Plessis, 2012), would make it a place where one is proud to live. This proposed case study would bring light on how the notion of 'place' might accommodate densely urban settings, as 'stories of place' presented in the literature are almost exclusively non-urban (Cole, 2012a).

"How to measure and evaluate progress is a major aspect of bringing about sustainability in urban contexts" (McCormick et al., 2013), and acknowledging that the set of indicators that we have used in this case study has room for further testing and improvement, its applicability on tracking the progress made by the case study city represents an important step in the field.

Carefully observing the evolution of this case study, in particular the role of institutions and their dynamics, would bring light into research needs identified by others in the field (Nevens et al., 2013).

\section{Conclusions}

This paper presents an innovative methodology for approaching the regenerative urban built environment concept focusing on municipal infrastructure systems or sub-systems (in this case stormwater management) with a holistic view.

Building upon literature and practice that supports a flexible approach to stormwater management in urban environments that mimic natural processes and predevelopment hydrology (SuDS) as one way to, amongst others, help to prevent and adapt to climate change, we highlight the relevance of the connection to the place for adoption of best practices that conduct towards a regenerative system. We incorporate it to the SuDS representation, naming it the SuDS 'landed rocket'.

The approach used in the Benaguasil journey towards a regenerative built environment can enlighten the path of other urban areas that share the same goal/vision but only see obstacles in their path. This urban scale case study located in the Mediterranean shows how, by focusing in one part of the complex system, while keeping a holistic approach, it is possible to make progress in only few years and have a promising future ahead.

To overcome the barriers that drag out progress, we identify two main enablers: a) A structured set of activities, the 'wheel', to guide and document the process, which is steered by a group of regional actors, the RWG, with a trans-disciplinary approach for systems-thinking, that starts with a stable small group of public policy and the academia actors, and with a shared vision grows to involve the remaining stakeholders as required (social scientists, ecologists, economists, design professions, public health experts, business institutions, civil society, community groups, the media); b) a visual and effective set of indicators, the wheel and the constellation (the SuDS 'landed rocket') maturation stage and 
trajectory, that monitors and assesses the progress achieved and identifies the strategies to move forward.

Integrating the views and strategies from actors at different but interconnected scales (from river basin down to individual buildings), following a structured but flexible methodology, opportunity emerges to combine efforts that catalyze the switch towards an urban built environment that supports a genuinely sustainable society.

\section{Acknowledgements}

This research has been conducted as part of the Life+ program project "AQUAVAL: Sustainable Urban Water Management Plans, promoting SUDS and considering climate change, in the province of Valencia" (Life08ENV/E/000099) and the MED program project "E2STORMED: Improvement of energy efficiency in the water cycle by the use of innovative storm water management in smart Mediterranean cities" (1C-MED12-14), both supported by ERDF funding of the European Union.

The authors would like to thank Prof. Chris Jefferies for his guidance throughout the projects and proof-reading of this article.

\section{References}

Agudelo-Vera, C.M., Mels, A.R., Keesman, K.J ., Rijnaarts, H.H.M. 2011. Resource management as a key factor for sustainable urban planning. J. Environ. Manage., 92, 10, 2295-2303. http://dx.doi.org/10.1016/j.jenvman.2011.05.016

Andrés-Doménech, I., Múnera, J.C., Francés, F., Marco, J.B., 2010. Coupling urban event-based and catchment continuous modelling for combined sewer overflow river impact assessment. Hydrol. Earth Syst. Sci., 14, 20572072. http://dx. doi.org/10.5194/hess-14-2057-2010.

Apostolaki, S., J efferies, C., Wild, T., 2006. The social impacts of stormwater management techniques. Water Pract. Technol., 1,

1. http://dx.doi.org/10.2166/WPT.2006009

Arnbjerg-Nielsen, K., Willems, P., Olsson, J., Beecham, S., Pathirana, A., Bülow G., I., Madsen, H., Nguyen, V.T.V., 2013. Impacts of climate change on rainfall extremes and urban drainage systems: a review. Water Sci. Technol., 68, 1, 1628. 
Bastien, N., Arthur, S., Wallis, S., Scholz, M., 2010. The best management of SuDS treatment trains: a holistic approach. Water Sci. Technol., 61, 1, 263272. http://dx.doi.org/10.2166/wst.2010.806

Biddulph, M., 2011. Urban design, regeneration and the entrepreneurial city. Progress in Planning, 76, 2, 63-

103. http://dx.doi.org/10.1016/j.progress.2011.08.001

Binney, P., Donald, A., Elmer, V. Ewert, J., Phillis, O., Skinner R., Young, R., 2010. IWA Cities of the Future Program. Spatial Planning and Institutional Reform Discussion Paper for the World Water Congress. Spatial Planning and Institutional Reform Working Group Report, Montreal, Canada. Last accessed 21May-2014

from http://www.iwahq.org/contentsuite/upload/iwa/document/updated\%20iwa $\% 20$ spatial\%20planning $\% 20$ and $\% 20$ institutional\% 20reform $\% 20$ group $\% 20 \mathrm{montr}$ eal\%20discussion\% 20paper.pdf

Brown, R.R., 2005. Impediments to Integrated Urban Stormwater Management: The Need for Institutional Reform. Environmental Management, 36, 3, 455468. http://dx.doi.org/10.1007/s00267-004-0217-4

Brown, R.R., Farrelly, M.A., 2009. Delivering sustainable urban water management: a review of the hurdles we face. Water Sci. Technol. 59, 5, 839846. http://dx.doi.org/10.2166/wst.2009.028

Brown, R.R., Keath, N., Wong, T.H.F., 2009. Urban water management in cities: historical, current and future regimes. Water Sci. Technol. 59, 5, 847855. http://dx.doi.org/10.2166/wst.2009.029

Brown, R.R., Farrelly, M.A., Loorbach, D.A., 2013. Actors working the institutions in sustainability transitions: The case of Melbourne's stormwater management. Global Environmental Change, 23, 4, 701718. http://dx.doi.org/10.1016/j.gloenvcha.2013.02.013

Campbell, N., D’Arcy, B., Frost, A., Novotny, V., Sansom, A., 2004. Diffuse pollution: an introduction to the problems and solutions. IWA Publishing, London. ISBN: 1-900222-53-1

Casal-Campos, A., J efferies, C., Perales-Momparler, S., 2012. Selecting SUDS in the Valencian Region of Spain. Water Pract. Technol. 7, 1, published online. http://dx.doi.org/10.2166/wpt2012.001

Castro-Fresno, D., Andrés-Valeri, V.C., Sañudo-Fontaneda, L.A., RodriguezHernandez, J., 2013. Sustainable Drainage Practices in Spain, Specially Focused on Pervious Pavements. Water, 5, 1, 67-

93. http://dx.doi.org/10.3390/w5010067 
Charlesworth, S.M., 2010. A review of the adaptation and mitigation of global climate change using sustainable drainage in cities. Journal of Water and Climate Change, 1, 3, 165-180. http://dx.doi.org/10.2166/wcc.2010.035

Charlesworth, S.M., Perales-Momparler, S., Lashford, C., Warwick, F., 2013. The sustainable management of surface water at the building scale: preliminary results of case studies in the UK and Spain. J. Water Supply Res. T., 62, 8, 534544. http://dx.doi.org/10.2166/aqua.2013.051

Chouli, E., Aftiasb, E., Deutscha, J.C., 2007. Applying storm water management in Greek cities: learning from the European experience. Desalination, 210, 6168. http://dx.doi.org/10.1016/j.desal.2006.05.033

Cole, R.J., 2012a. Regenerative design and development: current theory and practice. Building Research \& Information, 40, 1, 1-

6. http://dx.doi.org/10.1080/09613218.2012.617516

Cole, R.J., 2012b. Transitioning from green to regenerative design, Building Research \& Information, 40, 1, 39-

53. http://dx.doi.org/10.1080/09613218.2011.610608

de Haan, F.J., Ferguson, B.C., Adamowicz, R.C., J ohnsone, P., Brown, R.R., Wong, T.H.F., 2013. The needs of society: A new understanding of transitions, sustainability and liveability. Technol. Forecast. Soc. Change., 85, 121132. http://dx.doi.org/10.1016/j.techfore.2013.09.005

de Haan, J.H., Rotmans, J., 2011. Patterns in transitions: Understanding complex chains of change. Technol. Forecast. Soc. Change., 78, 90-

102. http://dx.doi.org/10.1016/j.techfore.2010.10.008

Díaz, M., Darnhofer, I., Darrot, C., Beuret, J.E., 2013. Green tides in Brittany: What can we learn about niche-regime interactions? Environ. Innovation Soc. Transitions, 8, 62-75. http://dx.doi.org/10.1016/j.eist.2013.04.002

du Plessis, C., 2012. Towards a regenerative paradigm for the built environment. Building Research \& Information, 40, 1, 7-

22. http://dx.doi.org/10.1080/09613218.2012.628548

Duffy, A. and Jefferies, C. 2011. Research Report: Developing a Framework to guide Urban Water Systems Transitions. SWITCH Deliverable D1.1.1. Last accessed on 13-May-2014

from http://www.switchurbanwater.eu/outputs/pdfs/W13_GEN_MAN_D1.3.3_SWITCH_Transition_Framework.pdf

Elzen, B., Geels, F.W., Leeuwis, C.S., Van Mierlo, B., 2011. Normative contestation in transitions 'in the making': animal welfare concerns and system innovation in pig husbandry (1970-2008). Research Policy, 40, 263-

275. http://dx.doi.org/10.1016/j.respol.2010.09.018 
Escuder-Bueno, I., Castillo-Rodríguez,J.T., Zechner, S., Jöbstl, C., PeralesMomparler, S., Petaccia, G., 2012. A quantitive flood risk analysis methodology for urban areas with integration of social research data. Nat. Hazards Earth Syst. Sci. 12, 2843-2863. http://dx.doi.org/10.5194/nhess-12-2843-2012

Escuder-Bueno, I., Andrés-Doménech, I., Morales-Torres, A., Perales-Momparler, S., 2013. Towards energy efficiency improvement in urban areas stormwater management: the E2STORMED project [in Spanish], in: Vallés-Morán, F.J., Andrés-Doménech, I., Escuder-Bueno, I., López-Jiménez, P.A., Marco S., J.B. (Eds), 2013, III Jornadas de Ingeniería del Agua. La protección contra los riesgos hídricos. Vol 2, pp. 51-58. ISBN: 978-84-267-2071-9

European Commission, 2012. Guidelines on Best Practices to Limit, Mitigate or Compensate Soil Sealing. Commission Staff Working Document. SWD(2012) 101 final/2. Brussels. Last accessed 21-May-2014 from http://ec.europa.eu/environment/soil/pdf/guidelines/EN\%20$\%$ 20Sealing\%20Guidelines.pdf

Ferguson, B.C., Brown, R.R., Deletic, A., 2013a. Diagnosing transformative change in urban water systems: Theories and frameworks. Global Environmental Change 23, 264-280. http://dx.doi.org/10.1016/j.gloenvcha.2012.07.008

Ferguson, B.C., Frantzeskaki, N., Brown, R.R., 2013b. A strategic program for transitioning to a Water Sensitive City. Landsc. Urban Plan., 117, 32-

45. http://dx.doi.org/10.1016/j.landurbplan.2013.04.016

Ferguson, B.C., Brown, R.R., de Haan, F.J., Deletic, A., 2014. Analysis of institutional work on innovation trajectories in water infrastructure systems of Melbourne, Australia. Environ. Innovation Soc. Transitions, In Press. http://dx.doi.org/10.1016/j.eist.2013.12.001

Frantzeskaki, N., Loorbach, D., Meadowcroft, J., 2012. Governing societal transitions to sustainability. International J ournal of Sustainable Development, 15, 1/2, 19-36. http://dx.doi.org/10.1504/IJSD.2012.044032

Gasper, R., Blohm, A., Ruth, M., 2011. Social and economic impacts of climate change on the urban environment. Current Opinion in Environmental Sustainability, 3, 150-157. http://dx.doi.org/10.1016/j.cosust.2010.12.009

Geels, F.W., 2004. From sectorial systems of innovation to socio-technical systems: Insights about dynamics and change from sociology and institutional theory. Research Policy, 33, 897-

920. http://dx.doi.org/10.1016/j.respol.2004.01.015

Geels, F.W., Schot, J., 2007. Typology of sociotechnical transition pathways. Research Policy, 36, 3, 399-417. http://dx.doi.org/10.1016/j.respol.2007.01.003 
Geels, F.W., 2011. The multi-level perspective on sustainability transitions: Responses to seven criticisms. Environ. Innovation Soc. Transitions, 1, 1, 2440. http://dx.doi.org/10.1016/j.eist.2011.02.002

Grau E., A., 1995. Benaguasil during the ancient regime [In Valencian]. I Imo. Ayuntamiento de Benaguasil, Valencia. ISBN:84-606-2634-2.

Hamel, P., Daly, E., Fletcher, D., 2013. Source-control stormwater management for mitigating the impacts of urbanisation on baseflow: A review. Journal of Hydrology, 485, 201-211. http://dx.doi.org/10.1016/j.jhydrol.2013.01.001

Hoxie, C., Berkebile, R., Todd, J.A., 2012. Stimulating regenerative development through community dialogue. Building Research \& Information, 40, 1, 6580. http://dx.doi.org/10.1080/09613218.2011.628546

Jefferies C., Duffy A.M., 2011. The SWITCH Transition Manual. ISBN 978-1899796-23-6. Last accessed 13-May-2014 from http://www. switchurbanwater.eu/outputs/pdfs/W13_GEN_MAN_D1.3.4_SWITCH_Transition_Manual.pdf

Jones, P.S., Davis, A.P., 2012. Spatial Accumulation and Strength of Affiliation of Heavy Metals in Bioretention Media. J. Environ. Eng., 139(4), 479487. http://dx.doi.org/10.1061/(ASCE)EE.1943-7870.0000624

Loorbach, D.A., 2007. Transition Management: New mode of Governance for sustainable development. PhD, Erasmus University, Rotterdam. ISBN: 978905727-057-4. Last accessed 13-May-2014 from http://repub.eur.nl/pub/10200

Loorbach, D., Rotmans, J., 2010. The practice of transition management: Examples and lessons from four distinct cases. Futures 42, 3, 237246. http://dx.doi.org/10.1016/j.futures.2009.11.009

Lundy, L., Wade, R., 2011. Integrating sciences to sustain urban ecosystem services. Progress in Physical Geography, 35, 5, 653-669.

. http://dx.doi.org/10.1177/0309133311422464

Mang, N.S., 2009. Toward a Regenerative Psychology of Urban Planning. Saybrook Graduate School and Research Center, ProQuest, UMI Dissertations Publishing, 3368975. Last accessed 21-May-2014 from http://gradworks.umi.com/33/68/3368975.html

Mang, P., Reed, B., 2012. Designing from place: a regenerative framework and methodology, Building Research \& Information, 40, 1, 23-

38. http://dx.doi.org/10.1080/09613218.2012.621341

Marsalek, J., Chocat, B., 2002. International Report: Stormwater management. Water Sci. Technol., 46, 6-7, 1-17. 
McCormick, K., Anderberg, S., Coenen, L., Neij, L., 2013. Advancing sustainable urban transformation. J. Clean Prod., 50, 1-

11. http://dx.doi.org/10.1016/j.jclepro.2013.01.003

Millán R., P., Nácher-Rodríguez, B., Hernández C., C., M. Martín, Vallés M., F.J., Andrés-Doménech, I., Perales-Momparler, S., 2013. Comparative analysis of runoff from a permeable pavement and from a conventional road [In Spanish], in: Vallés-Morán, F.J ., Andrés-Doménech, I., Escuder-Bueno, I., López-J iménez, P.A., Marco S., J.B. (Eds), 2013, III Jornadas de Ingeniería del Agua. La protección contra los riesgos hídricos. Vol 2, pp. 131-138. ISBN:978-84-2672071-9

Næss, P., Vogel, N. 2012. Sustainable urban development and the multi-level transition perspective. Environ. Innovation Soc. Transitions, 4, 36-

50. http://dx.doi.org/10.1016/j.eist.2012.07.001

Nevens, F., Frantzeskaki, N., Gorissen, L., Loorbach, D., 2013. Urban Transition Labs: co-creating transformative action for sustainable cities, J. Clean Prod., 50, 111-122. http://dx.doi.org/10.1016/j.jclepro.2012.12.001.

Nicolau B., J., 1990. Pages of Benaguasil history [in Valencian]. Ajuntament de Benaguasil, Benaguasil. ISBN: 84-505-9891-5.

Novotny, V., Ahern, J., Brown, P., 2010. Water centric sustainable communities: planning, retrofitting, and building the next urban environment. John Wiley \& Sons, Inc. New Jersey. ISBN 978-0-470-47608-6

Pahl-Wostl, C., Tàbara, D., Bouwen, R., Craps, M., Dewulf, A., Mostert, E., Ridder, D., Taillieu, T., 2008. The importance of social learning and culture for sustainable water management. Ecological Economics, 64, 3, 484-

495. http://dx.doi.org/10.1016/j.ecolecon.2007.08.007

Pedersen-Zari, M., 2012. Ecosystem services analysis for the design of regenerative built environments. Building Research \& Information, 40, 1, 54 64. http://dx.doi.org/10.1080/09613218.2011.628547

Perales, S., Andrés, I., 2008. Sustainable Urban Drainage Systems: An alternative for Stormwater Management [In Spanish]. Revista Técnica de Medio Ambiente C\&M Publicaciones, Madrid, pp. 92-104. ISSN: 1130-9881

Perales, S., Valls, G., Coombs, P., 2011. Pluvial flood hazard maps: tools and case studies [In Spanish], in: Escuder-Bueno, I., Matheu, E., Itarejos-García, L., Castillo-Rodríguez, J.T. (Eds), 2012, Risk Analysis, Dam Safety, Dam Security and Critical Infrastructure Management, Taylor \& Francis Group, London, pp. 129-137. ISBN 978-0-415-62078-9.

Perales-Momparler, S., Valls-Benavides, G., 2013. Sustainable Drainage Systems (SuDS). Paisea no 024: Espacios del Agua. Paisea revista s.I. ISSN 1887-2557 
Perales-Momparler, S., Hernández-Crespo, C., Vallés-Morán, F., Martín, M., Andrés-Doménech, I., Andreu A., J., Jefferies, C., 2014. SuDS Efficiency during the Start-Up Period under Mediterranean Climatic Conditions. Clean-Soil Air Water 2014, 42 (2), 178-186. http://dx.doi.org/10.1002/clen.201300164

Perales-Momparler, S., J efferies, C., Periguell-Ortega, E., Peris-García, P.P., Munoz-Bonet, J.L., 2013. Inner-city SUDS retrofitted sites to promote sustainable stormwater management in the Mediterranean region of Valencia: AQUAVAL (Life+ EU Programme). NOVATECH Conference, Lyon, France.

Plaut, J.M., Dunbar, B., Wackerman, A., 2012. Regenerative design: the LENSES Framework for buildings and communities, Building Research \& Information, 40, 1, 95-111. http://dx.doi.org/10.1080/09613218.2012.619685

Potter, K., Ward, S., Shaw, D., Macdonald, N., White, I., Fischer, T., Butler, D., Kellagher, R., 2011. Engineers and planners: sustainable water management alliances. Engineering Sustainability, 164, ES4, 239-

247. http://dx.doi.org/10.1680/ensu.2011.164.4.239

Progress Consulting S.r.I. and Living Prospects Ltd., 2011. The role of regional and local authorities in promoting a sustainable water policy. Final Survey Report. Doc cdr-180. European Union. Last accessed $13^{\text {th }}$-May- 2014 from http://portal.cor.europa. eu/europe2020/news/Documents/Water/Water\%2 0Survey\%20Full\%20Report\%20Final.pdf

Quist, J., Thissen, W., Vergragt, P.J., 2011. The impact and spin-off of participatory backasting: From vision to niche. Technol. Forecast. Soc. Change, 78, 883-897. http://dx.doi.org/10.1016/j.techfore.2011.01.011

Rauch., W., Seggelke, K., Brown, R., Krebs, P., 2005. Integrated Approaches in Urban Storm Drainage: Where Do We Stand? Environmental Management, 35, 4, 396-409. http://dx.doi.org/10.1007/s00267-003-0114-2

Reed, B., 2007. Shifting from 'sustainability' to regeneration. Building Research \& Information, 35, 6, 674-680. http://dx.doi.org/10.1080/09613210701475753

Reed, M.S., Graves, A., Dandy, N., Posthumus, H., Hubacek, K., Morris, J., Prell, C., Quinn, C.H., and Stringer, L.C., 2009. Who's in and why? A typology of stakeholder analysis methods for natural resource management. J. Environ. Manage., 90, 5, 1933-1949. http://dx.doi.org/10.1016/j.jenvman.2009.01.001

Resolution of $31^{\text {st }}$ October 2013, of the Infrastructure, Territory and Environment Regional Ministry, submitting to public information the revision of the Territorial Action Plan on Flood Risk prevention for the Valencian Region [In Spanish]. Diario Oficial de la Comunidad Valenciana 2013, 7159, 34289-34290. 
Rotmans, J., Kemp, R., van Asselt, M., 2001. More evolution than revolution: transition management in public policy. Foresight, 3, 1, 15-

31. http://dx.doi.org/10.1108/14636680110803003

Royal Decree 1290/2012 of $7^{\text {th }}$ September amending both the Royal Decree 849/1986 of 11 April, approving the Regulation of Public Water, and Royal Decree 509/1996 of 15 March, developing the Royal Decree Law 11/1995 of December 28, laying down rules for urban waste water treatment [in Spanish]. Boletín Oficial del Estado 2012, 227, 66167-66194.

Royal Decree 233/2013 of $5^{\text {th }}$ April regulating the National Plan to encourage house renting, building refurbishment and urban regeneration and renovation, 2013-2016 [in Spanish]. Boletín Oficial del Estado 2013, 86, 26623-26684.

Sánchez-Rodríguez, R., 2009. Learning to adapt to climate change in urban areas. A review of recent contributions. Current Opinion in Environmental Sustainability, 1, 2, 201-206. http://dx.doi.org/10.1016/j.cosust.2009.10.005

Smith, A., 2007. Translating Sustainabilities between Green Niches and SocioTechnical Regimes. Technology Analysis \& Strategic Management, 19, 4, 427450. http://dx.doi.org/10.1080/09537320701403334

Smith, A., Raven, R., 2012. What is protective space? Reconsidering niches in transitions to sustainability. Research Policy, 41, 6, 10251036. http://dx.doi.org/10.1016/j.respol.2011.12.012

Truffer, B., Störmer, E., Maurer, M., Ruef, A., 2010. Local strategic planning processes and sustainability transitions in infrastructure sectors. Environmental Policy and Governance, 20, 4, 258-269. http://dx.doi.org/10.1002/eet.550

Tukker, A., Butter, M., 2007. Governance of sustainable transitions: about the 4(0) ways to change the world. J. Clean Prod., 15, 1, 94-

103. http://dx.doi.org/10.1016/j.jclepro.2005.08.016

United States Environmental Protection Agency (USEPA), 2008. Managing wet weather with Green Infrastructure. Green Streets. Low Impact Development Center, EPA, USA. Last accessed 21-May-2014

from http://water.epa.gov/infrastructure/greeninfrastructure/upload/gi_municha ndbook_green_streets.pdf

van der Brugge, R., Rotmans, J., 2007. Towards transition management of European water resources. Water Resour. Manag., 21, 1, 249-

267. http://dx.doi.org/10.1007/s11269-006-9052-0

van der Steen, P., Howe, C., 2009. Managing water in the city of the future; strategic planning and science. Rev. Environ. Sci. Biotechnol., 8, 115120. http://dx.doi.org/10.1007/s11157-009-9154-2 
van Herk, S., Zevenbergen, C., Ashley, R., Rijke, J., 2011. Learning and Action Alliances for the integration of flood risk management into urban planning: a new framework from empirical evidence from The Netherlands. Environmental Science \& Policy, 14, 5, 543-

554. http://dx.doi.org/10.1016/j.envsci.2011.04.006

Willems, P., Olsson, J., Arnbjerg-Nielsen, K., Beecham, S., Pathirana, A., Bülow G., I., Madsen, H., Nguyen, V.T.V., 2012. I mpacts of Climate Change on Rainfall Extremes and Urban Drainage Systems. IWA Publishing. ISBN: 9781780401256

Wong, T.H.F., Brown, R.R., 2009. The water sensitive city: principles for practice. Water science and technology, 60, 3, 673-

682. http://dx.doi.org/10.2166/wst.2009.436

Woods-Ballard, B., Kellagher, R., Martin, P., J efferies, C., Bray R.; Shaffer, P., 2007. The SUDS Manual. CIRIA C697. London. ISBN: 978-0-86017-697-8

Woolthuis, R., Hooimeijer, F., Bossink, B., Mulder, G., Brouwer, J., 2013. Institutional entrepreneurship in sustainable urban development: Dutch successes as inspiration for transformation. J. Clean Prod., 50, 91-

100. http://dx.doi.org/10.1016/j.jclepro.2012.11.0 